\title{
DOKUMENTA
}

Dr MILAN GULIĆ, naučni saradnik

Institut za savremenu istoriju

Beograd, Trg Nikole Pašića 11

milan.gulic@gmail.com

kritičko izdanje naučne građe

primljeno: 25. septembar 2016.

prihvaćeno: 8. februar 2017.

\section{DIPLOMATIJA U PREDVEČERJE OLUJE. ZAPISNIK RAZGOVORA MILANA MARTIĆA I ALVARA DE SOTA U KNINU 8. JULA 1995.*}

Ljeto 1995. donijelo je rasplet u građanskom ratu u Hrvatskoj koji je buktio još od 1991. Izdvajanje Republike Hrvatske (RH) iz okvira Socijalističke Federativne Republike Jugoslavije (SFRJ) pratio je krvavi građanski rat između hrvatskih vlasti i srpskog stanovništva na dijelu „avnojevske“ teritorije te republike u koji je u prvoj fazi sukoba bila upletena i Jugoslovenska narodna armija (JNA). Vlasti u Zagrebu nisu imale kontrolu nad teritorijom na kojoj je decembra 1991. proglašena Republika Srpska Krajina (RSK) koju niko nije priznao, ali koja je imala razgranatu državnu vlast, administrativni sistem, vojsku, policiju i koja je predstavljala stranu u razgovorima o razriješenju krize. Od proljeća 1992. ta teritorija se nalazila pod zaštitom Ujedinjenih nacija (UN) prema planu koji je projektovao američki diplomata od ugleda Sajrus Vens.

Iako je tzv. Vensovim planom bila predviđena demilitarizacija Zaštićenih zona Ujedinjenih nacija (Zona Jug sa sjedištem u Kninu, Sjever sa sjedištem u Topuskom, Zapad sa sjedištem u Daruvaru i Istok sa sjedištem u Erdutu) i prestanak oružanih dejstava kako bi se stvorili uslovi za konačno mirno rješenje krize, sukoba je bilo i u narednom periodu. Akcije Hrvatske vojske (HV) na Miljevačkom platou u junu 1992, ${ }^{2}$ u Ravnim kotarima u januaru 1993. ${ }^{3}$ i u Medačkom džepu u septembru $1993 .{ }^{4}$

* Rad je dio projekta Konflikti i krize: saradnja i razvoj u Srbiji i regionu u 19. i 20. veku (47030) koji finansira Ministarstvo prosvete, nauke i tehnološkog razvoja Republike Srbije.

${ }^{1} \mathrm{O}$ početku rata na prostoru Hrvatske, proglašenju RSK i implementaciji Vensovog plana više u: Nikica Barić, Srpska pobuna u Hrvatskoj 1990.-1995 (Zagreb: Golden marketing-Tehnička knjiga, 2005), 111-166; Коста Новаковић, Српска Крајина: успони, падови, уздизања (Београд: Српско културно друштво Зора, 2009), 91-147, 153-169, 182-191; Срђан Радуловић, Судбина Крајине (Београд: Српско културно друштво Зора, 2015²), 33-60; Милан Гулић, „Проглашење Републике Српске Крајине: у сјенци Венсовог плана“, у: Грађански рат у Хрватској 1991-1995, XI-XII, Зборник радова, уредник Милојко Будимир (Београд: Удружење Срба из Хрватске, Српско културно друштво Зора, Српска читаоница др Јован Рашковић, 2016), 274-337.

${ }^{2}$ Miljevci Plateau June 1992. Victims of Croatian Agression in the Republic of the Serbian Krajina (Knin: Veritas, 1994). 
pokazale su da mirovne snage nisu donijele mir, već samo primirje i to varljivo. Tek su Sporazum o prekidu vatre iz marta 1994. ${ }^{5}$ i Ekonomski sporazum iz decembra 1994. učinili da se prilike barem malo stabilizuju, da se otvori auto-put i stvori privid normalnosti. Naravno, onoliko koliko je to bilo moguće u okolnostima višegodišnjeg krvavog građanskog rata.

Međutim, politički sukobi unutar RSK i sporenja oko produženja mandata snaga UN zaoštravali su situaciju u prvim mjesecima 1995. Sve je kulminiralo krajem aprila incidentima na dijelu auto-puta koji je bio pod kontrolom srpskih snaga. Hrvatska je to iskoristila za pokretanje vojne operacije velikog zamaha pod nazivom Bljesak u rano jutro 1. maja kojom je ovladala dijelom Sektora Zapad, to jest Zapadne Slavonije koja se nalazila pod srpskom kontrolom. Vojni poraz 18. korpusa Srpske vojske Krajine (SVK) i nezainteresovanost Knina koja se ogledala u činjenici da avijacija nije reagovala, a snage koje je trebalo prikupiti po ostalim korpusima nisu poslate u ugroženu regiju, pokazali su svu ozbiljnost situacije u RSK, slabost njenih oružanih snaga i uticali na porast političke krize u Krajini. ${ }^{6}$ Situaciju su dodatno usložnjavale poruke iz Zagreba koji je bio ohrabren brzom i efikasnom akcijom u Zapadnoj Slavoniji. Predsjednik RH dr Franjo Tuđman otvoreno je poručio: „Ukoliko ne odustanu od oružanog otpora (Srbi u Krajini - prim. aut.) Hrvatska će znati i moći da uspostavi vlast nad čitavom teritorijom u svojim međunarodno priznatim granicama na način na koji je to učinjeno i prekjuče i juče u zapadnoj Slavoniji." I predsjednik saborskog Odbora za mirnu reintegraciju, rodom iz benkovačkog kraja Drago Krpina, istakao je da je akcija hrvatskih oružanih snaga u Zapadnoj Slavoniji „primjer kako će se raditi i sa drugim dijelovima Krajine“. 7

O složenosti političkih i, možemo reći, opštih prilika u Krajini u proljeće i ljeto 1995. govorio je i predsjednik RSK Milan Martić u pismu predsjedniku Republike Srbije Slobodanu Miloševiću ukazujući da se „duž cijele Krajine širi glas o njenoj prodaji“, kao i da se u mnogim selima i gradovima ,narod pakuje i sprema na iselja-

${ }^{3}$ Ravni Kotari - Maslenica 1993. Victims of Croatian Agression in the Republic of the Serbian Krajina (Knin: Veritas, Iskra, 1994).

${ }^{4}$ Bloody September in Lika 1993 (Knin: Veritas, Iskra, 1994); Zvonimir Despot, Medački džep 1993. (Zagreb: Večernji list, 2012).

${ }_{5}$ Republika Hrvatska i Domovinski rat 1990.-1995. Dokumenti, XI, Dokumenti vojne provenijencije „Republike Srpske Krajine“ (siječanj-lipanj 1994.) (Zagreb: Hrvatski memorijalnodokumentacijski centar Domovinskog rata, 2012), 268-273.

${ }^{6}$ O padu Zapadne Slavonije više u: Milisav Sekulić, Knin je pao u Beogradu (Bad Vilbel: Nidda Verlag GmBH, 2001²), 97-120; Ivan Brigović, „Osvrt na operaciju Bljesak u dokumentima Republike Srpske Krajine“, Časopis za suvremenu povijest, XL, br. 1, (2009), 39-70; Julija Barunčić Pletikosić, Željka Križe Gračanin, „Ustroj i djelovanje 18. korpusa Srpske vojske Krajine“, u: Srpska pobuna u zapadnoj Slavoniji 1990.-1995.: nositelji, institucije, posljedice, Zbornik radova, urednici Ivica Miškulin i Mladen Barać (Slavonski Brod-Zagreb: Hrvatski institut za povijest - Podružnica za povijest Slavonije, Srijema i Baranje, Hrvatski memorijalno-dokumentacijski centar Domovinskog rata, 2012), 163-181; Слободан Перић, Западна Славонија у светлу југословенске кризе 1991-1995. Истине, заблуде и обмане (Београд: Лицеј, 2014), 88-107.

7 „Или повратак у Хрватску или нови блиц-криг“, Политика, 5. 5. 1995, 7; „Противречне изјаве хрватских челника“, Политика, 6. 5. 1995, 7. 
vanje“ ${ }^{8}$ Pad Zapadne Slavonije pratila su optuživanja među političarima o tome ko snosi krivicu za takav ishod, došlo je do smjene na mjestu komandanta SVK, a zbog osjećaja krivice ostavku je podnio i jedan od ministara u Vladi. Politička kriza je kulminirala u sukobu između predsjednika RSK Milana Martića i predsjednika Vlade Borislava Mikelića, kroz koji su se reflektovali i rđavi odnosi u trouglu BeogradPale-Knin. Pitanje ujedinjenja između Republike Srpske Krajine i Republike Srpske, koje je ponovo pokrenuto u danima nakon kraha u Zapadnoj Slavoniji, predstavljalo je vrhunac sukoba u krajinskom rukovodstvu.

Kao i prethodni i taj projekat ujedinjenja ostao je „mrtvo slovo na papiru“, međutim potpuno udaljeni stavovi između Martića i Mikelića, ali i unutar samog Mikelićevog kabineta, doveli su do pada Vlade koja je zavrijedila oreol najdugotrajnije u inače kratkoj istoriji RSK. Upravo je Mikelićevo protivljenje ujedinjenju navedeno kao formalan razlog zašto je 29. maja zatraženo i izglasano obaranje njegove Vlade. Na sjednici Skupštine na kojoj je smijenjen Mikelić otvoreno je još jedno važno pitanje - problem ,secesije koja je u toku“ u istočnom dijelu RSK, čvrsto naslonjenom na Srbiju i vlast u Beogradu. Potezi Knina oko najave ujedinjenja nisu nailazili na odobrenje u istočnom dijelu Krajine (Baranja, Istočna Slavonija i Zapadni Srem) i učinili su da te oblasti, faktički, više ne priznaju vlast Knina i da se tamo učvrsti „Vlada u ostavci“" Borislava Mikelića.

Prilike u Krajini dodatno je zaoštravalo napredovanje hrvatskih snaga na masivu Dinare na koje se, čini se, u Krajini nije dovoljno obratila pažnja. Očekivalo se da to pitanje riješi Vojska Republike Srpske (VRS) kako je i obećavano iz Banjaluke. Hrvatske snage su na padine Dinare prodrle još krajem 1994, zatim radile na ojačanju komunikacija i dopremanju tehnike, a onda ponovo napredovale aprila 1995. Napredovanje na masivu Dinare intenzivirano je poslije uspješno obavljene akcije Bljesak, a cilj je bio da se prekine komunikacija Knin-Grahovo i tako onemogući veza između dva dijela RSK, ali i veze zapadnog dijela RSK sa Republikom Srpskom (RS) i Saveznom Republikom Jugoslavijom (SRJ). Osim toga, trebalo je izbiti na visove sa kojih se krajinska prestonica „vidi kao na dlanu“. ${ }^{10}$

U takvim okolnostima 3. jula u Knin je stigla delegacija Međunarodne konferencije o bivšoj Jugoslaviji koju su predvodili kopredsjednici Torvald Stoltenberg i Karl Bilt i koja je, nakon razgovora u Zagrebu, pokušala da ubijedi Knin da pristane na pregovore sa Hrvatskom. Dok je predsjednik Martić bio uporan u stavu da od nekakvih pregovora sa Hrvatskom nema nikakve koristi i da će Zagreb prekršiti svaki dogovor, Bilt je upozoravao da su prilike takve da se ,suočavamo sa dilemom: pregovori ili rat“ i da u Zagrebu ,ima mnogo onih koji čekaju vaše ne da pošalju tenko-

${ }^{8}$ Davor Marijan, Oluja (Zagreb: Hrvatski memorijalno-dokumentacijski centar Domovinskog rata, 2009), 216-217.

${ }^{9}$ Hrvatski memorijalno-dokumentacijski centar Domovinskog rata (HMDCDR), fond Skupština Srpske autonomne oblasti/Republike Srpske Krajine (3), kutija 9, Skraćeni zapisnik sa 4. sjednice I redovnog zasjedanja Skupštine RSK, održane u Kninu 29. maja 1995. godine; Nikica Barić, „O okolnostima i posljedicama smjene predsjednika vlade Republike Srpske Krajine Borislava Mikelića 1995. godine“, Istorija 20. veka, XXVIII, br. 3, (2010), 151-168.

${ }^{10}$ HMDCDR, fond Kabinet predsjednika/Služba predsjednika Republike Srpske Krajine (62), kutija 1, Vanredni operativni izveštaj GŠ SVK, 04.06.1995. 
ve na Krajinu“. Još otvoreniji je bio bivši komandant Zaštitnih snaga UN (UNPROFOR - United Nations Protection Forces) general Bertran de la Prel koji je otvoreno poručio: „Ako se ne ode na pregovore solucija će biti strašna vojna opcija.“ Njihov dolazak bio je potez Evropske zajednice kao jednog od spoljnih činilaca sveukupne jugoslovenske krize. ${ }^{11}$

Poslije Evropske zajednice početkom jula 1995. diplomatsku misiju poslale su i UN. U Knin je 8. jula stigao pomoćnik generalnog sekretara UN Butrosa Butrosa Galija peruanski diplomata Alvaro de Soto. ${ }^{12}$ On je, takođe, prije dolaska u Knin boravio u Zagrebu, što je bila uobičajena maršruta raznih medijatora upletenih u građanski rat u Hrvatskoj. Peruanac je u Kninu razgovarao sa trećim (i posljednjim) predsjednikom RSK Milanom Martićem. ${ }^{13}$ Važnost tog razgovora je bila višestruka.

${ }^{11}$ Republika Hrvatska i Domovinski rat 1990.-1995. Dokumenti, XVIII, Dokumenti institucija pobunjenih Srba u Republici Hrvatskoj (svibanj-kolovoz 1995.) (Zagreb-Slavonski Brod: Hrvatski memorijalno-dokumentacijski centar Domovinskog rata, Hrvatski institut za povijest - Podružnica za povijest Slavonije, Srijema i Baranje, 2012), 276-279.

${ }^{12}$ Alvaro de Soto (rođen 16. marta 1943), peruanski diplomata, pravnik, školovan u Ženevi i Limi. Radio u okviru peruanskih misija pri UN u Njujorku i Ženevi. U administraciju UN uključio se 1982. kao specijalnih savjetnik tek izabranog generalnog sekretara, takođe Peruanca, Havijera Pereza de Kueljara (1982-1991). Bio je zadužen za mirovni proces u Centralnoj Americi. Tokom 1991. i 1992. predvodio je pregovore koji su doveli do sklapanja mirovnog sporazuma i okončanja višegodišnjeg građanskog rata u Salvadoru (1979-1992). Od februara 1992. do decembra 1994. bio je specijalni savjetnik novog generalnog sekretara Egipćanina Butrosa Butrosa Galija (1992-1996) i učestvovao je u mirovnim misijama u Jugoslaviji, Haitiju i Somaliji. Od 1995. do 1997. bio je pomoćnik generalnog sekretara za političke poslove zadužen za Ameriku, Evropu, Aziju i Pacifik. Predstavljao je UN u razgovorima između Indonezije i Portugala koji su se ticali Istočnog Timora, a bio je i specijalni izaslanik generalnog sekretara Kofija Anana (1997-2006) u Mjanmaru (1997-1999). Kao specijalni savjetnik generalnog sekretara radio je zatim na Kipru (1999-2004), kao specijalni izaslanik u Zapadnoj Sahari (2003-2005), a zatim kao specijalni koordinator na Bliskom istoku (2005-2007). Autor je više novinskih članaka i poglavlja u knjigama. Gostujući je predavač u Paris School of International Affairs i viši saradnik u Ralphe Bunche Institutu. Član je Global Leadership Foundation i savjetodavnih odbora u nekoliko foruma, centara i grupa u Njujorku, Amsterdamu i Parizu. http://www.g-l-f.org/index.cfm?id=23711 (pristupljeno 29. 8. 2016); https://www.ictj.org/about/alvaro-de-soto (pristupljeno 29. 8. 2016)

${ }^{13}$ Milan Martić (rođen u Žagroviću kod Knina 18. novembra 1954), policijski službenik i političar. Školovao se na Višoj policijskoj školi u Zagrebu. Radio je kao policijski službenik u Sekretarijatu unutrašnjih poslova u Šibeniku (1976-1981) i policijski inspektor u Kninu (1982-1990). U središte pažnje došao je avgusta 1990. kada je hrvatska policija pokušala oduzeti oružje rezervnog sastava iz gradova sa srpskom većinom, a kninska policija, zajedno sa stanovništvom kome je prethodno podijelila to oružje, podigla barikade. Martić je postepeno postajao ključna figura u kninskoj policiji, a zatim i na daleko širem području od Knina. Kada je Srpska autonomna oblast (SAO) Krajina (proglašena 21. decembra 1990) formirala svoj Sekretarijat unutrašnjih poslova 4. januara 1991. Martić je postavljen za sekretara. S obzirom na to da je policija predstavljala jedinu naoružanu formaciju te autonomne regije njegov značaj je sve više rastao. Bio je ministar unutrašnjih poslova u Vladi SAO Krajine (29. maj-19. decembar 1991) i vladama RSK Milana Babića, Zdravka Zečevića i Đorđa Bjegovića (19. decembar 1991-21. april 1994). Za predsjednika RSK izabran je na izborima 26. januara 1994. i na tom mjestu je ostao do sloma RSK 5. avgusta 1995. Pošto je protiv njega podignuta optužnica 25. jula 1995, predao se Međunarodnom krivičnom tribunalu za bivšu Jugoslaviju u Hagu 15. maja 2002. Presudom od 12. juna 2007. osuđen je na 35 godina zatvora za ,progone, ubistva, pritvaranja, torturu, nehumana djela, okrutno postupanje, deportacije, nasilna premještanja, bezobzirno razaranje sela ili pustošenje koje nije opravdano vojnim potrebama, kršenje zakona i običaja ratovanja, uništavanje ili nasumično nanošenje štete obrazovnim i vjerskim ustanovama, pljačkanje javne i privatne imovine i napade na civile“. Kaznu izdržava u zatvoru u Tartuu, Estonija. http://www.icty.org/x/cases/martic/tjug/en/070612.pdf (pristupljeno 29. 8. 2016) 
Sam De Sotov dolazak zbio se u vrlo delikatnom trenutku, a sve ono što je izrečeno pokazalo je najbolje kakve su bile opšte prilike u međunarodnim odnosima i shvatanja i očekivanja jedne od sukobljenih strana, kao i međunarodne zajednice. Dok je krajinski predsjednik uporno zastupao stav o nezavisnosti RSK i nemogućnosti života unutar Hrvatske, De Soto je, manirom iskusnog diplomate, pokušavao da mu stavi do znanja da za takav ishod nema podršku ni od koga. Dokument je pohranjen u Hrvatskom memorijalno dokumentacijskom centru Domovinskog rata u Zagrebu u fondu Kabinet predsjednika/Služba predsjednika Republike Srpske Krajine (broj fonda 62), u kutiji broj 1. Dokument je pisan ćirilicom.

REPUBLIKA SRPSKA KRAJINA

SLUŽBA PREDSJEDNIKA REPUBLIKE

DRŽAVNA TAJNA

ANALITIČKO-INFORMATIVNA SLUŽBA

Broj: 020/4-2-709-2/95

Knin, 12.07.1995

\section{ZAPISNIK}

sa sastanka Predsjednika RSK, g. Milana Martića

sa Pomoćnikom Generalnog Sekretara,

g. Alvaro de Soto

Datum: 08. jul 1995. god.

Vrijeme: 12,30 časova

Mjesto: Kabinet Predsjednika RSK

Prije početka razgovora, prijateljsko ćaskanje u „Plavom salonu“ gdje je održan sastanak.

Predsjednik daje riječ de Sotu.

\section{ALVARO DE SOTO}

Svrha moje posjete - ja kao pomoćnik Generalnog Sekretara, Butrosa Galija, nadležan sam za vaš dio svijeta. Moram priznati da su problemi veoma složeni. Kako bi se shvatilo stanje, nisu dovoljni izvještaji. Upravo zbog toga sam došao da razgovaram sa rukovodstvom i da osetim stanje na terenu.

Druga namera je da vidim kako vaša opozicija djeluje u praksi. Bio sam u Zagrebu dva dana sa Šarinićem ${ }^{14}$ i Granićem. ${ }^{15}$ Posetio sam Bosnu i Hercegovinu Sarajevo i Mostar. Posjetio sam Makedoniju. Juče sam bio u Beogradu. Nakon Knina idem u Zapadnu i Istočnu Slavoniju. Međutim, glavni cilj moje posjete je razgovor sa Vašim rukovodstvom. Da čujem Vaše želje. Koje su. Kako Vam mogu pomoći, jer ću savjetovati Generalnog Sekretara, Butrosa Galija.

Zahvalan sam na prijemu. Nadam se da ćete u svom izlaganju imati ovo u vidu.

\footnotetext{
${ }^{14}$ Hrvoje Šarinić, u to vrijeme šef/predstojnik Ureda predsjednika Republike Hrvatske, a prethodno i predsjednik Vlade (avgust 1992-april 1993).

${ }_{15}$ Mate Granić, ministar vanjskih poslova u vladama Nikice Valentića (april 1993-novembar 1995) i Zlatka Mateše (novembar 1995-januar 2000).
} 
MILAN MARTIĆ, predsjednik RSK

Predsjednik pozdravlja goste i zaželio im prijatan boravak u Kninu. Zatim Predsjednik predstavlja svoje saradnike:

1. gen. M. Mrkšić, Komandant VRSK, ${ }^{16}$

2. Ilija Prijić, savjetnik Predsjednika ${ }^{17}$

3. Dušan Pralica, savjetnik Predsjednika

I ovaj put vodi zapisnik sa ovog sastanka.

Da bi ste shvatili situaciju, prezentiraću Vam genezu sukoba sa Hrvatima. Historija je često dosadna, ali se bez nje ne može shvatiti sadašnje stanje.

Prisutnost Srba na ovim prostorima oko hiljadu godina.

Kao dokaz za to su srpski manastiri i ostali dokumenti.

Barem smo ovdje onoliko koliko i Hrvati.

Nelogično je da smo okupatori vlastitih kuća. Četiri vijeka imamo svoju državnost - od Austrougarske.

Ovaj prostor je bio Vojna Krajina - štit Zapada od Turaka.

Od tadašnje Austro-ugarske smo 1652 god. dobili državnost. Poslije toga smo bili susjedi sa Hrvatima, do prije 150 godina. Tada se pojavljuje Ante Starčević sa svojim monstruoznim programom. Po tom programu trećinu Srba je trebalo pobiti, trećinu asimilirati - pokatoličiti i trećinu protjerati. Taj program je zaživio u dvadesetom vijeku - u prvom i drugom svjetskom ratu, kada je stradalo preko milion Srba. U oba svjetska rata bili smo sa saveznicima (SAD, Engleska, Francuska, Rusija) kao pobjednici. Hrvati oba puta na drugoj strani. Saradnici fašista. I pored genocida koji su izvršili na nama Srbima, pristali smo živjeti s njima u jednoj državi. Ono što je najvažnije je da su Srbi bili državotvoran narod kao i Hrvati.

Nikad nismo bili nacionalna manjina u Hrvatskoj, kako Hrvati govore. U svim Ustavima od 1918. god. do danas, do 1990. g. bili smo ustavotvoran narod.

${ }^{16}$ Mile Mrkšić (rođen 20. jula 1947. u Kozarcu kod Vrginmosta), oficir Jugoslovenske narodne armije, Vojske Jugoslavije i Srpske vojske Krajine. Školovao se na Vojnoj akademiji i Komandnoštabnoj akademiji. Službovao je u garnizonima u Titogradu i Beogradu. Izbijanje sukoba na tlu Jugoslavije dočekao je u činu pukovnika kao komandant Gardijske motorizovane brigade (1988-1992). Učestvovao je u borbama u Istočnoj Slavoniji od 15. septembra do 24. novembra 1991. Ubrzo nakon toga vanredno je unaprijeđen u čin general-majora. Kao komandant specijalnih jedinica (1992-1993) bio je stacioniran na području Banije i Korduna od 1. januara do 15. aprila 1992. U borbenim dejstvima je ponovo bio od 22. januara do 24. decembra 1993. Vanredno je unaprijeđen u čin general-potpukovnika 16. juna 1994. Penzionisan je 30. decembra iste godine sa mjesta pomoćnika načelnika Generalštaba Vojske Jugoslavije. Za komandanta SVK izabran je 18. мaja 1995. i na tom mjestu je ostao sve do njene propasti u avgustu 1995. kada je ponovo penzionisan. Međunarodni krivični tribunal za bivšu Jugoslaviju podigao je optužnicu protiv njega 26. oktobra 1995. Dobrovoljno se predao Tribunalu 15. maja 2002, a 27. septembra 2007. osuđen je na 20 godina zatvora za ,ubistva, mučenja, okrutno postupanje i kršenje običaja rata" nad ratnim zarobljenicima na farmi Ovčara pored Vukovara 20. i 21. novembra 1994. Na izdržavanje kazne poslat je 16. avgusta 2012. u Lisabon u Portugalu, gdje je preminuo 16. avgusta 2015. Sahranjen je u Beogradu na groblju Lešće. http://www.icty.org/x/cases/mrksic/cis/bcs/cis_mrksic_al_bcs.pdf (pristupljeno 29. 8. 2016) http://www.icty.org/x/cases/mrksic/tjug/en/070927.pdf (pristupljeno 29. 8. 2016); Boško Antić, Radovan Tomanović, Branko Fezer i Petar Škrbić, Generali i admirali Srbije 19812011. Biografski rečnik (Beograd: Klub generala i admirala Srbije, 2012), 250-251.

${ }^{17}$ Ilija Prijić, bivši šef kninske policije, a zatim ministar unutrašnjih poslova u Vladi Borislava Mikelića (april-novembar 1994). 
To se može provjeriti. Tipično za nas je praštanje, ali ne zaboravljamo. Posebno u drugom svjetskom ratu $\mathrm{NDH}^{18}$ sa Antom Pavelićem na čelu, izvršen je genocid nad srpskim narodom. Najveće stratište je Jasenovac. Tu je na najsvirepiji način pobijeno 600000 Srba i 100000 Jevreja, Roma i Hrvata - protivnika režima Ante Pavelića.

Obzirom na vođu NOB-e, ${ }^{19}$ Josip Broz, Hrvat - vješto je preveo Hrvate među pobjednike, podvaljujući Srbima, što sada trpimo. Izmislio je Republike i Srbe podelio u nekoliko cjelina. To su avnojevske komunističke granice. Zapad od komunizma priznao samo te granice. I ta Titova Jugoslavija je nestala po principu samoopredjeljenja. Tako je i formirana Hrvatska u kojoj smo konstitutivni narod. Prihvatili smo teoriju bratstva-jedinstva. Ustavi od 1944-1990. god. pokazuju da smo ustavotvoran narod. Međutim, pobjedom HDZ ${ }^{20}$ 1990.g. na višestranačkim parlamentarnim izborima, mjenja se situacija.

Pobjedom Tuđmana, forsira se svest o oživotvorenju NDH iz drugog svjetskog rata - ustaška svest.

U Saboru, bez prisustva Srba, izbacuju nas iz Ustava i proglašavaju nacionalnom manjinom. Ponovo vraćaju simbole iz NDH i sve ono što asocira na ustaškofašističku tvorevinu, što izaziva nespokojstvo kod srpskog stanovništva. Tako masovno preimenuju ulice sa antifašističkim u fašističke nazive (Trg žrtava fašizma u Trg hrvatskih vladara, a vladar je bio i Ante Pavelić). Ruše se spomenici antifašista itd.

Srpski narod počeo se organizovati zbog novog genocida koji mu prijeti. I prije sukoba Tuđman proteruje iz Hrvatske preko 300000 Srba. Primjer imamo ovdje. Moj savjetnik mr Ilija Prijić i njegov brat radili su u Zagrebu kao profesori. Protjerani su, prije toga izbačeni sa posla, samo zato što su Srbi.

O ovome ima niz dokaza da je to bila naredba Franje Tuđmana, a proveo je HDZ, vladajuća stranka u Hrvatskoj. Čak i zločince su pustili iz pritvora i postali mu saradnici (ubice porodice Zec). ${ }^{21}$

Samoorganizovali smo se zbog zaštite golih života.

Hrvatska je bila u sastavu SFRJ. Međunarodna zajednica (SAD i Njemačka pre svih), razbija Jugoslaviju. Po principu samoopredjeljenja svi su mogli izići iz SFRJ. Mi smo opstanak vidjeli u Jugoslaviji. Međunarodna zajednica priznaje secesionizam Hrvatske i Slovenije i to po principu republika a ne po principu samoopredjeljenje naroda. $U$ protivnom išli bi bez nas i bili priznati.

\footnotetext{
${ }^{18}$ Nezavisna Država Hrvatska.

${ }^{19}$ Narodnooslobodilačka borba.

${ }^{20}$ Hrvatska demokratska zajednica.

${ }^{21}$ Srbin Mihajlo Zec ubijen je u svojoj kući u Poljaničkoj ulici u Zagrebu 7. decembra 1991.
} kada mu je nekoliko naoružanih pripadnika rezervnog sastava Ministarstva unutarnjih poslova RH upalo u kuću oko 23 sata. Supruga Marija i 12-godišnja ćerka Aleksandra odvezene su u pravcu Sljemena, ubijene i pokopane u jamu blizu planinarskog doma Adolfovac. Za ubistvo su osumnjičeni Siniša Rimac, Munib Suljić, Igor Mikola, Nebojša Hodak i Snježana Živanović. Iako su nekoliko dana nakon zločina uhapšeni i priznali djelo, jula 1992. Okružni sud u Zagrebu ih je oslobodilo zbog nedostatka dokaza i „nezakonito prikupljenih dokaza“. Rimac je, štaviše, nosilac osam visokih državnih odlikovanja, a radio je i kao član obezbjeđenja ministra obrane Gojka Šuška. http://www.rts.rs/page/stories/sr/story/11/Region/418331/Mesi\%C4\%87+pomilovao+zlikovca.html (pristupljeno 29. 8. 2016) 
Ovdje Međunarodna zajednica čini grešku i priznaje Titove granice. Počinje progon JNA kao okupatora, a paravojna Hrvatska vojska se priznaje za regularnu. U Ustavu je stajalo da je JNA bila sastavljena od svih naroda i narodnosti. Najvažnija uloga joj je štićenje Ustava i poredka.

Zahvaljujući Genšeru ${ }^{22}$ i Kolu, ${ }^{23}$ stvorena je nezabilježena medijska kampanja o lažnoj slici u Jugoslaviji. Satanizacija cjelokupnog srpskog naroda.

U međuvremenu počinje rat sa svim svojim posljedicama. Šalje se Badinterova komisija. $^{24}$

Po toj komisiji kriteriji za državnost su:

- posjedovanje teritorije

- uspostavljena vlast na cjelokupnoj teritoriji

- narod koji živi na toj teritoriji

Nije bilo uslova za priznavanje državnosti Hrvatskoj, jer nije ispunila niti jedan uslov:

- teritorijalna necjelovitost

- nemaju narod na teritoriju koji ne kontrolišu

- nemaju vlast na našoj teritoriji

Mi smo stvorili svoju državu na svom etničkom teritoriju koji obuhvata oko $16000 \mathrm{~km}^{2}$.

- Formirali smo vlast nakon provedenih višestranačkih predsjedničkih i parlamentarnih izbora 1993. godine

- Naš narod živi na našoj teritoriji

Nikada nismo ni živjeli u NDH Franje Tuđmana.

Pristali smo na dolazak UNPROFOR-a i mnogo od njega očekivali.

Proglašeni smo ZAŠTIĆENOM ZONOM, na koju je izvršeno četiri puta agresija od Hrvata.

1. Jun 1992. godine - Miljevac; Savjet Bezbjednosti donosi odluku da se povuku, ali ništa ne ispoštuju Hrvati.

2. Januar 1993. godine - Maslenica i Ravni Kotari, opet ista priča;

3. Septembar 1993. godine - Medački džep u Lici, opet ista priča

Apsurd da SB ne kažnjava Hrvate. Tragedija je da se nama donosi blokada a nalazimo se pod zaštitom UN. Cijelo vrijeme želimo biti kooperativni. U pregovorima želeli smo da imamo ravnopravni status. Marta 1994. godine potpisujemo u Zagrebu Sporazum o prekidu vatre. Poslije smo ušli u ekonomske sporazume. I tu smo pokazali visoki stepen kooperativnosti. Krenulo je dobro.

${ }^{22}$ Hans-Ditrih Genšer, vicekancelar i ministar inostranih poslova Savezne Republike Njemačke (1982-1992).

${ }^{23}$ Helmut Kol, kancelar Savezne Republike Njemačke (1982-1998).

${ }^{24}$ Arbitražna komisija je formirana u okviru Međunarodne konferencije o bivšoj Jugoslaviji koja je kolokvijalni naziv dobila prema svom predsjedniku francuskom pravniku Roberu Badinteru. Ustanovljena je odlukom Savjeta ministara Evropske zajednice od 27. avgusta 1991. Komisiju su činili predsjednici ustavnih sudova pet zemalja članica EZ - Francuske, Njemačke, Španije, Belgije i Italije. U pogledu Jugoslavije dala je 15 pravnih mišljenja među kojima je najvažnije ono prema kojem su dotadašnje republičke granice postajale međudržavne. 
Očito da im mirni način nije odgovarao. Uz podršku sponzora vrše novu (četvrtu) agresiju u maju ove godine -01.05.1995. $\mathrm{g}$.

U međuvremenu došlo je do promjene mandata UNPROFOR-a.

Sa agresijom u Z. Slavoniji pokazali su svoje lice. To je ono što želimo dokazati da njih ne interesuje srpski narod, već srpski etnički prostor.

U Z. Slavoniji počinjen je genocid nad srpskim narodom, neviđen do sada u svijetu.

Izvršeno je etničko čišćenje Z. Slavonije u dva djela:

1. 1990-1991. god.

2. maj 1995. god.

Na tim prostorima živjelo je 150000 Srba. Sva ta mjesta - Novska, Pakrac, Okučani, Lipik, Požega, Podravska Slatina, Grubišno Polje - bila su srpska, jer je srpski narod bio većinski (60\% Srba).

Sada su Hrvati te prostore etnički očistili. Ono malo Srba što je ostalo, je obespravljeno. Svi žele izaći. ${ }^{25}$

Ono što nas zabrinjava jeste nedelotvornost SB. Očekivali smo više objektivnosti od UN. Izgubili su povjerenje od Srba. Ne znamo što im je svrha. Neophodno je nešto preduzeti da se Hrvati kazne. Trebalo je i moralno je da se Hrvatskoj uvedu sankcije.

Poslije Z. Slavonije Hrvatska je krenula na Dinaru, jer nisu kažnjeni za sve navedene agresije, posebno na Z. Slavoniju. Sigurni su u podršku Njemačke i Amerike. Ubeđeni smo da će nas napasti opet.

Mi jesmo za pregovore, za mirno rješenje sukoba. Međutim, kako dalje da pregovaramo, ako Hrvati ne poštuju ono što je dogovoreno i što potpišu. Ništa do sada nisu ispoštovali.

Svi pregovori poslije okupacije Z. Slavonije su prekinuti.

Uslovi da dođe do pregovora se moraju ostvariti, a to su:

- da se Hrvati povuku sa Dinare;

- da se Z. Slavonija demilitarizuje i stavi pod protektorat UN;

- da nam se omogući tranzit robe iz jednog djela RSK u drugi preko Srbije;

Savet Bezbednosti treba to da reguliše Rezolucijom ili da nam se to prećutno omogući. To bi povratilo izgubljeno povjerenje u UN kod srpskog naroda.

DA ZAKLJUČIM:

Mi ne želimo rat. Želimo mirno rješenje. Međunarodna zajednica treba da nas uzme ozbiljno u razmatranje i tada ćemo moći doći do rezultata. Prisustvo samo jed-

${ }^{25}$ Martić ovdje navodi sasvim proizvoljan podatak. Od navedenih opština Srbi su imali većinu samo u Pakracu (od 24.932 stanovnika, srpske nacionalnosti je bilo 12.813) i Okučanima koji su pripadali opštini Nova Gradiška (od 1.979 stanovnika, bilo je 1.642 Srba). Tijesnu većinu Srbi su imali u Lipiku koji je pripadao opštini Pakrac (od 3.208 stanovnika, Srba 1.499, a Hrvata 1.447). Hrvati su činili većinu stanovništva u Novskoj (od 24.696 stanovnika bilo je 5.402 Srba), Požegi (od 68.079 stanovnika 9.759 Srba), Podravskoj Slatini (od 29.390 stanovnika bilo je 11.212 Srba) i Grubišnom Polju (od 13.150 stanovnika, Hrvata 6.015, a Srba 4.540). Popis stanovništva, domaćinstava, stanova i poljoprivrednih gospodarstava 31. ožujak 1991. Stanovništvo prema narodnosti po naseljima (Zagreb: Republički zavod za statistiku Republike Hrvatske, 1992), 98-99, 134-135, 138-139, 152-153, 156-159, 162-169. 
ne strane u sukobu u UN i SB doprinosi donošenju subjektivnih (neobjektivnih) odluka. Otuda i apsurdan zaključak UN da je ovo okupirana teritorija.

Otiđite u bilo koju kuću u RSK i utvrdite jesu li oni okupatori. Ovo je sve posledica što nam nisu omogućili da kažemo svoje argumente u UN i SB. Moj zahtjev SB i Butrosu Galiju je da čuju od nas naše argumente u Generalnoj Skupštini i SB. Naše prisustvo, tamo je neophodno i uslov je za pravedno rješenje.

Taj zahtjev smatramo opravdanim jer je Gali primio Albance sa Kosova.

Možda sam bio preopširan ali morao sam sve ovo izneti radi objektivnog prilaza i sagledavanja naše stvarnosti.

\section{ALVARO DE SOTO}

Sve ovo je korisno da čujem. To je i svrha mog dolaska. Niste bili dosadni. Naprotiv, vaše zalaženje u istoriju je utvrdilo moje znanje. Znamo da su UN ovdje od 1992. godine.

Za vrijeme boravka i mi smo propatili, zbog niza prilika. Donošene su preuranjene odluke gdje su naši čelnici napravili greške. Ne mogu govoriti u ime SB, ali je B. Gali dao oštre osude na preuranjene odluke. Njegovi saveti nisu poslušati. Naposletku će rješenje zavisiti od dogovora dve strane. Mi moramo omogućiti mir. Također, žalimo što UN nisu uvek bile kadre da ispune zahtjeve obe strane. Međutim, Međunarodna zajednica nema namjeru da nameće rješenje. Moramo objektivno izvještavati. Nezadovoljni ste odlukom UN. Neka Vam je utjeha da i druga strana ne uživa bolji položaj.

Zatečen sam u Zagrebu, predlogom mogućeg rješenja. Nadamo se da će se prići pregovorima. Generalni Sekretar je u Ženevi, sa pomoćnicima. Ove slutnje o ratu će biti na dnevnom redu.

Cilj nam je prekid vatre, a onda povratiti povjerenje u iznalaženje privrednog dogovora.

Nastojimo napraviti uslove da se razgovori nastave.

VRATITI POVJERENJE U SUKOBLJENE STRANE DA ŽIVE ZAJEDNO. $^{26}$

Moramo omogućiti povratak izbjeglica uz poštovanje njihovih prava. Što se mene tiče, predstaviti Vaše stavove. Razumite i Vi B. Galija, jer ne može on omogućiti sam Vaš govor u Generalnoj Skupštini. To odlučuje SB, osim ako se ne desi nešto dramatično. Posebno na ovo razdoblje, da nismo na kraju sa mandatom UNCRO-a. ${ }^{27}$

Generalni Sekretar je zabrinut mogućnošću nastavka rata. Moramo izgraditi mostove za razgovore. Moram izraziti, još jednom, zahvalnost za pruženu priliku da razgovaram sa Vama, što ste odvojili vrijeme za mene.

Došao sam kao student, željan znanja. Ovdje sam dosta saznao iz Vašeg izlaganja.

MILAN MARTIĆ, predsjednik RSK

\footnotetext{
${ }^{26}$ Velika slova u izvorniku, kao i u nastavku teksta.

${ }^{27}$ UNCRO - United Nations Confidence Restoration Organization, tj. Operacija Ujedinjenih nacija za obnovu povjerenja. Ustanovljena Rezolucijom 981 Savjeta bezbjednosti UN od 31. marta 1995.
} 
Mislim da ste iskusni diplomata i da shvatate složenost situacije. Da se razumijemo. Mi nismo imali sponzora u svijetu. Ne tražimo od Vas da priznate svoju grešku. Takav zahtjev nije realan. Bilo bi potrebno da se prećutno ispravi nepravda koja nam je nanešena. Prva mjera jeste da se omogući protok roba između dva dijela RSK, te da se počnu uzimati u raspravu.

I laiku je jasno da je nemoguć život nas Srba sa Hrvatima. Tražimo da i naš narod iznese svoj stav. Neka Međunarodna zajednica bude prisutna na referendumu našeg naroda o tome s kim želi živjeti. Dakle, još jednom smo spremni pred svijetom sprovesti referendum o samoopredjeljenju. Ako Srbi odluče da žive ponovo sa Hrvatima, nemamo ništa protiv. Moje procjene su, a to je pokazano na dva plebiscita, da srpski narod, ne želi da živi sa Hrvatima. Srbi bi prihvatili da žive sa Francuzima, Japancima i drugim narodima ali ne u Hrvatskoj sa Hrvatima. Razumijete zbog čega. Zbog genocida Hrvata nad Srbima u nekoliko navrata. To što mi tražimo je minimum - što ima pravo jedan narod.

Po mom mišljenju, kada bi RSK bila priznata, brzo bi se dogovorili sa komšijama Hrvatima. Prekinula bi se neprijateljstva i sarađivali bi. Takav primjer imate sa Francuskom i Njemačkom, sa tom razlikom što niko nije činio zločine kao Hrvati.

Ako vam je stalo do mira, uzmite naše argumente u razmatranje. ${ }^{28}$

\section{ALVARO DE SOTO}

Hvala Vam i na ovom objašnjenju. Ne bih se mogao složiti sa svim iznesenim. Ozbiljno sumnjam da imate nekog u svijetu ko bi mogao da Vam pomogne da tako rješite situaciju.

Međunarodna zajednica nije sklona da usvoji raskid između dva strane. Dug je period zajedničkog života Hrvata i Srba.

Međunarodna zajednica i SB osjetili su da je rješenje blizu nakon dva dogovora. (Zagrebački sporazum o prekidu vatre i ekonomski sporazum - op. d. p.) ${ }^{29}$

Siguran sam da Gali veruje da ćemo ukloniti radikalnije opcije.

Imam utisak da je sve ovdje blizu - ljudi, navike, jezik i ostalo. Bliskost.

Volio bih da mislim da su ljudi osuđeni da žive jedni s drugima. Suživot bi se mogao ostvariti sa suzdržanošću i međunarodnim dogovorom.

Danas sam došao da primim znanja, a ne da ih nudim, ne nudim rješenja.

Mislim da je Međunarodna zajednica nesklona da prihvati centrifugalne tendencije. Drugim rječima, predočavam atmosferu u UN i SB. Ne mogu Vas nagovoriti da usvojite ono što ću reći. Nažalost u svetu koji je međusobno zavisan, postoje zemlje koje zanemaruju značaj velikih sila.

MILAN MARTIĆ, predsjednik RSK

Vjerujem da Gali ili nema dobre procjene ili nije upoznat. Nije problem u ekstremima u Hrvatskoj vlasti. Hrvatski narod je dao povjerenje Tuđmanu. Program i drugih stranaka je skoro identičan HDZ-eu, što se tiče nas Srba.

\footnotetext{
${ }^{28}$ Podebljano u izvorniku, kao i u nastavku teksta.

${ }^{29}$ Skraćenica ,op. d. p.“ označava „opasku Dušana Pralice“ koji je vodio zapisnik.
} 
Ono što je najvažnije, je program Ante Starčevića koji se kontinuirano realizuje; to je nacionalni program Hrvata. To sam Vam objasnio. U takvoj državi je nemoguće živjeti.

Tvrdimo slijedeće: Mi nemamo izbor za mir. Ako bi prihvatili to što nudite, to bi bilo ropstvo za moj narod, i naravno, to ne možemo prihvatiti. Ili će Međunarodna zajednica to rješiti, uvažavajući princip samoopredjeljenja, ili će rat trajati.

Tjerati žrtvu na domet mača dželata, priznaćete, nije humano. To nikome ne ide u prilog. Za tu tvrdnju je najbolji primjer Zapadna Slavonija.

\section{ALVARO DE SOTO}

Po mom viđenju moramo politikom pregovora odvratiti ratnu opciju. Otvoreno ste odlučili da sprovedete pravo na samoopredjeljenje. Osim toga ste se pozvali na Povelju UN. Međutim, možda je put u sredini (kompromisno rješenje - op. d. p.).

MILAN MARTIĆ, predsjednik RSK

Nehumano je tražiti od mene da svoj narod privedem na klanje. Da smo imali zaštitu u svetu, što nismo, problem bi već bio rješen. Mi smo narod sa tradicijom.

Ako Amerikanci misle da smo mi neki Indijanci, onda se varaju, da ćemo u rezervat.

Tačno je da je i kod nas prisutan strah, ali ovaj narod je opredjeljen do konačne pobjede. Čvrsto smo uvjereni da smo u pravu da će Međunarodna zajednica uvidjeti greške i da ćemo živjeti u miru.

\section{ALVARO DE SOTO}

Potpuno sam razumio Vašu odlučnost. Uvjeravam Vas da ću prenijeti Butrosu Galiju sve što ste rekli.

Odlazim sa mnogo jasnijom slikom što se ovdje dešava, iako svrha nije prenošenje poruke. svijetu.

Nadam se da ovo nije uzalud utrošeno vrijeme i da ste shvatili odnose u

Još jednom hvala na vremenu koje ste mi dali.

MILAN MARTIĆ, predsjednik RSK

Još dve rečenice. Bez objektivnog pristupa Međunarodne zajednice ne može se riješiti ovaj problem, a biće najveća greška ako se ovo smatra unutrašnjim problemom Hrvatske.

Svetski su ovo problemi. I prije nego što dam riječ gen. Mrkšiću, zahvaljujem na posjetu i neka ih bude više.

GEN. MILE MRKŠIĆ, komandant VRSK

U ime Srpske Vojske Vas pozdravljam i želim da se prijatno osećate u svakom dijelu RSK.

Zaključio sam što nam je raditi. Predsjednik je istakao da nam cilj MIR. Mi ne ugrožavamo MIR. Uvek smo žrtve. Sada pripremam Vojsku koja neće biti žrtva, već 
pobednik. Prenesite da se sve učini da se izbjegne sukob, koji Hrvati pripremaju i da neće biti kao u Z. Slavoniji. Formirali smo jake snage, koje su snabdjevene najsavremenijim raketnim sistemima i koje mogu širiti i na Evropu. Pogotovo što najviše stradaju civili. Ne želimo da stradaju hrvatski civili, već vojni objekti.

Generali koji su ratovali ne žele rat. Tako i sam poslednje je što želim rat. Zato ubedite Hrvate, da ne dođe do rata. Želimo da sednemo i pregovaramo. Danas politika prizna onoga ko je jak. Ukoliko budemo snažni, odvratićemo sve agresije. Tada će lakše doći do rešenja. To je naš doprinos miru. Cilj je mir - izbjeći rat.

\section{ALVARO DE SOTO}

Zahvalan sam Vam, g. Generale na ovako finim rečima. Neke pretpostavke su me ohrabrile, da ne dođe do rata.

Uživate poštovanje kao general. Drago mi je da mrzite rat. Iskreno se nadam da zakoni sile neće nadvladati, te da ćemo preći na konkretna pitanja za vezu sa Hrvatskom.

\section{SAVJETNIK FUNKCIONERA}

Dušan Pralica

P. S.

U delegaciji de Sota bile su dve dame i jedan gospodin. Obe dame su vodile cijelo vrijeme zapisnik. Vidljivo je bilo da su sa posebnom pažnjom bilježile izlaganje Predsjednika Republike Srpske Krajine.

SAVJETNIK FUNKCIONERA

Dušan Pralica, s. r.

\section{IZVORI I LITERATURA}

- Hrvatski memorijalno-dokumentacijski centar Domovinskog rata, Zagreb

- Skupština Srpske autonomne oblasti/Republike Srpske Krajine (3)

- Kabinet predsjednika/Služba predsjednika Republike Srpske Krajine (62)

- Bloody September in Lika 1993. Knin: Veritas, Iskra, 1994.

- Despot, Zvonimir. Medački džep 1993. Zagreb: Večernji list, 2012.

- Miljevci Plateau June 1992. Victims of Croatian Agression in the Republic of the Serbian Krajina. Knin: Veritas, 1994.

- Popis stanovništva, domaćinstava, stanova i poljoprivrednih gospodarstava 31. ožujak 1991. Stanovništvo prema narodnosti po naseljima. Zagreb: Republički zavod za statistiku Republike Hrvatske, 1992.

- Ravni Kotari - Maslenica 1993. Victims of Croatian Agression in the Republic of the Serbian Krajina. Knin: Veritas, Iskra, 1994.

- Republika Hrvatska i Domovinski rat 1990.-1995. Dokumenti, XI, Dokumenti vojne provenijencije „Republike Srpske Krajine“ (siječanj-lipanj 1994.). Zagreb: Hrvatski memorijalno-dokumentacijski centar Domovinskog rata, 2012. 
- Republika Hrvatska i Domovinski rat 1990.-1995. Dokumenti, XVIII, Dokumenti institucija pobunjenih Srba u Republici Hrvatskoj (svibanj-kolovoz 1995.). ZagrebSlavonski Brod: Hrvatski memorijalno-dokumentacijski centar Domovinskog rata, Hrvatski institut za povijest - Podružnica za povijest Slavonije, Srijema i Baranje, 2012.

- Политика, Београд (1995)

- Antić Boško, Tomanović Radovan, Fezer Branko, i Petar Škrbić. Generali i admirali Srbije 1981-2011. Biografski rečnik. Beograd: Klub generala i admirala Srbije, 2012.

- Barić, Nikica. Srpska pobuna u Hrvatskoj 1990.-1995. Zagreb: Golden marketingTehnička knjiga, 2005.

- Barić, Nikica. „O okolnostima i posljedicama smjene predsjednika vlade Republike Srpske Krajine Borislava Mikelića 1995. godine“. Istorija 20. veka, XXVIII, br. 3, (2010), 151-168.

- Barunčić Pletikosić Julija, i Željka Križe Gračanin. „Ustroj i djelovanje 18. korpusa Srpske vojske Krajine“. U: Srpska pobuna u zapadnoj Slavoniji 1990.-1995.: nositelji, institucije, posljedice, Zbornik radova. Urednici Ivica Miškulin i Mladen Barać, 163-181. Slavonski Brod-Zagreb: Hrvatski institut za povijest - Podružnica za povijest Slavonije, Srijema i Baranje, Hrvatski memorijalno-dokumentacijski centar Domovinskog rata, 2012.

- Brigović, Ivan. „Osvrt na operaciju Bljesak u dokumentima Republike Srpske Krajine“. Časopis za suvremenu povijest, XL, br. 1, (2009), 39-70.

- Гулић, Милан. „Проглашење Републике Српске Крајине: у сјенци Венсовог плана“. У: Грађански рат у Хрватској 1991-1995., ХI-ХII, Зборник радова. Уредник Милојко Будимир, 274-337. Београд: Удружење Срба из Хрватске, Српско културно друштво Зора, Српска читаоница др Јован Рашковић, 2016.

- Marijan, Davor. Oluja. Zagreb: Hrvatski memorijalno-dokumentacijski centar Domovinskog rata, 2009.

- Новаковић, Коста. Српска Крајина: успони, падови, уздизања. Београд: Српско културно друштво Зора, 2009.

- Перић, Слободан. Западна Славонија у светлу југословенске кризе 1991-1995. Истине, заблуде и обмане. Београд: Лицеј, 2014.

- Радуловић, Срђан. Судбина Крајине. Београд: Српско културно друштво Зора, $2015^{2}$.

- Sekulić, Milisav. Knin je pao u Beogradu. Bad Vilbel: Nidda Verlag GmBH, $2001^{2}$.

- http://www.g-l-f.org/index.cfm?id=23711 (pristupljeno 29. 8. 2016)

- https://www.ictj.org/about/alvaro-de-soto (pristupljeno 29. 8. 2016)

- http://www.icty.org/x/cases/martic/tjug/en/070612.pdf (pristupljeno 29. 8. 2016)

- http://www.rts.rs/page/stories/sr/story/11/Region/418331/Mesi\%C4\%87+pomilova o+zlikovca.html (pristupljeno 29. 8. 2016)

- http://www.icty.org/x/cases/mrksic/tjug/en/070927.pdf (pristupljeno 29. 8. 2016)

- http://www.icty.org/x/cases/mrksic/cis/bcs/cis_mrksic_al_bcs.pdf (pristupljeno 29. 8. 2016) 